\title{
BAIL REFORM IN AMERICA
}





\section{BAIL REFORM IN AMERICA}

WAYNE H. THOMAS, JR.

Foreword by Floyd Feeney

UNIVERSITY OF CALIFORNIA PRESS

BERKELEY LOSANGELES LONDON 
University of California Press

Berkeley and Los Angeles, California

University of California Press, Ltd.

London, England

Copyright () 1976 by

The Regents of the University of California

ISBN 0-520-03131-8

Library of Congress Catalog Card Number: 75-27936

Printed in the United States of America 